\title{
The Efforts of State-Owned Entreprises in Managing Human Resources Amid the Coronavirus Pandemic:
}

\author{
Should They be Fired?
}

\author{
Oktaviani Permatasari*, Yuyu Jahratu Noor Santy, Ratna Agustina \\ University of Mayjen Sungkono \\ Mojokerto, Indonesia \\ *oktavianipermatasari99@gmail.com, yuyujahratu@gmail.com, ratna.agustina.26@gmail.com
}

\begin{abstract}
Managing human resources among the coronavirus pandemic is a very important aspect. Human resource management must be carried out optimally so that needs related to individual, company, organizational or institutional goals can be achieved so that it is hoped that the shortcomings and problems faced by the Indonesian people, which are related to the State's efforts in managing human resources between the coronavirus pandemic can be resolved. This paper aims to describe and analyze whether the termination of employment is the best decision. In addition, the State also makes spending savings ( $K / L$ and TKDD expenditures) which are not prioritized according to changes in conditions in $\mathbf{2 0 2 0}$, as well as the latest government effort is to prepare a perpu to be issued by the government with three main things, first, policies and extraordinary steps. (extraordinary) in saving the national economy and financial system stability, second, through various relaxation related to the implementation of the 2020 State Budget, and third, strengthening the authority of various institutions in the financial sector. The Perpu also anticipates the possibility of a deficit which is estimated to reach 5.07 percent. The results of rapid observations show that the visible changes that have occurred due to COVID-19 are seen in various aspects of life; individual behaviour, community response, business and economic conduct, State governance, and global relations. According to the Minister of Manpower, as many as 3.05 million (as of 2 June 2020) people must be sent home affected by COVID19 and estimates that additional unemployment could reach 5.23 million.
\end{abstract}

Keywords—state enterprise, managing human resources, coronavirus

\section{INTRODUCTION}

The continuity of a company is determined by both internal and external factors [1]. The COVID-19 pandemic currently occurring is an external factor, so it requires special handling to reduce the bad things that happen [1]. In the initial study on the Management of COVID-19 in Indonesia, it was stated that when the COVID-19 outbreak broke out, several countries were affected, including Indonesia, so the government had to take a stance in handling this pandemic systematically [2]. One of the steps taken by the government is the issuance of
Government Regulation in place of Law (Perpu) Number 1 of 2020 concerning State Financial Policy and Financial System Stability for Handling the COVID-19 pandemic and/or to face threats that endanger the national economy and/or stability. finance, March 31, 2020 [2]. This Perpu serves as a legal basis for budget adjustments under current extraordinary conditions, as well as a justification for an increase in the 2020 State Budget expenditure and financing, with a total additional expenditure and financing for the 2020 State Budget of Rp. 405.1 trillion [2].

According to Solanki, the role of management between HR and HR functions in making negative strategic decisions is at a higher level of dynamism [3]. Once the moderating effect of the dynamic environment is taken into account, there is a positive relationship between the excessive role of human resources and conflict with the involvement of human resources in strategic decision making [3].

According to Malik \& Purwanto, the impact of the rapid and widespread spread of COVID-19 was felt in the business ecosystem in Indonesia [4]. State-Owned Enterprises (SOE) are business entities entrusted with managing state businesses that contain the interests of many people, contributing to national economic growth and a source of state revenue [4]. On the other hand, long before COVID-19 occurred, many SOE continued to record losses and needed an injection of funds from the State [4].

The problem is how SOE efforts to manage human resources in it involving employees among the COVID-19 pandemic. Does it have an impact on employee dismissal, considering that these two SOE sectors with different trends are most affected by the COVID-19 pandemic, namely the transportation sector and the pharmaceutical sector [2]? This is the urgency in this writing, SOE sector services decline due to government regulations, including social restrictions, travel tires, lockdowns and work from home [2]. This has caused the transportation sector SOE to maintain its performance even with decreased and limited income, but on the other hand, the pharmaceutical SOE sector has experienced a significant increase with the addition of COVID-19 cases continuously 
[2]. This creates confusion for pharmaceutical SOEs because so far $90 \%$ of the pharmaceutical industries in Indonesia are still imported (PT Bio Farma Persero) 2018. With the decline in the productivity of various manufacturers of raw materials for drugs and drugs, the pharmaceutical sector is threatened by experiencing constraints in the production chain [2].

The purpose of this study is to provide an understanding that with SOE efforts to manage Human Resources in the era of the COVID-19 pandemic, it is crucial to be addressed because after all employees have the right to continue working even during a pandemic like this. The research is expected to be useful as a national scientific reference with the learning experience method as a recommendation in managing Human Resources during the COVID-19 pandemic. The data obtained can clarify problem-solving or provide unknown information so that it can be known. And then it can solve the problem if the data obtained in this study is useful to minimize or even eliminate problems.

\section{LITERATURE REVIEW}

\section{A. Implementation of HR Regulations in the Era of the COVID-19 Pandemic}

The Ministry of Administrative Reform and Bureaucratic Reform on March 16, 2020, instructed to stay at home or work from home during the COVID-19 outbreak (Ministry of Administrative and Bureaucratic Reform, 2020). All employees are encouraged to work from home unless they have to be in a public place for emergencies [5]. Among the 273 million Indonesians who have been instructed to stay at home, the impact could have a major impact on the Indonesian economy beyond the spread of COVID-19 itself [5]. As a developing country, Indonesia has 760 thousand entrepreneurs who must continue to work outside the home, although some are still able to condition themselves to work from home, which can reduce costs [6]. Meanwhile, this social distancing arrangement affects those who have to work outside, so that they become unemployed for various reasons [7]. Weak management crisis resulted in 1.9 million Indonesians losing their jobs during this pandemic [8]. Therefore, addressing the economic impact of COVID-19 can be done through the practice of staying at home, with incentives and rewards that must be addressed to protect economic activity [9].

The Indonesian government, recently also provided social security programs for those affected by COVID-19, including the Family Hope Program (IDR 37.4 trillion), Basic Food Social Assistance (IDR 2.2 trillion), Village Fund (IDR 21 trillion), the Labor Intensive Cash Program (Rp. 16.9 trillion), and the Pre-Employment Card Program (Rp. 360 billion). These programs are expected to reduce the burden on society related to the economic impact of COVID-19.

\section{B. SOE Crisis Management Capabilities during COVID-19}

The Impact of COVID-19, Which Threatens Not Only Human Health, But Also the Economic Condition Shows the
Importance of Implementing Good Crisis Management, Where SOEs Are Active to Fulfill Government Requests Through Instructions to Serve the Community, But Still Lacking in Initiating What to Do During This Pandemic [2]. Including Responding to the Negative Impacts of COVID-19, and to Protect Employees as Important Company Assets in the future, SOEs need to be more active in taking initiatives to respond to all the impacts of a crisis, through good crisis management, especially to maintain company performance and protect employees [2]. Especially in times of crisis such as COVID-19, SOEs are expected to be better prepared to solve problems, because these efforts are important considering that the government, which usually provides support to SOEs, has various obligations whose priorities increase during a crisis [2].

\section{METHODS}

This study uses a descriptive exploratory approach that analyzes SOE efforts in managing human resources between the COVID-19 pandemic, will SOE employees be fired in the presence of the pandemic. By developing a literature review of research results from various published international, national and local research journals and electronic newspapers. A theory/concept approach is also carried out by referring to several sources, such as books, scientific journals, and the internet. All descriptions of existing ideas are combined in one arrangement of thought frameworks which will then be abstracted into the results of research findings and issued recommendations for $\mathrm{SOE}$ in managing human resources during the COVID-19 pandemic.

\section{RESULTS AND DISCUSSION}

\section{A. Results}

The Indonesian government finally issued a serious policy related to the widespread transmission of the virus with a significant number of deaths [10]. Perpu No.1 / 2020 concerning State Financial Policy and Financial System Stability for Handling the COVID-19 Pandemic is the initial basis for a series of policies in various sectors [10]. The additional 2020 state budget expenditure funds amounting to IDR 405.1 trillion, based on this Perppu covers four main areas, namely: health, economic recovery, social safety nets, and industrial support [10]. Over time and seeing the development of the COVID-19 outbreak which turned out to have a very serious impact on the national economy, the government has revised APBN spending three times, the first revision (March 2020: Rp. 405.1 trillion), the second revision (May 2020: Rp. 641.17 trillion) and the third revision (June 2020: Rp. 677, 2 trillion) here it is explained that SOE in the second revision is budgeted at Rp. $135.34 \mathrm{~T}$ to cover 12 SOEs, especially in the form of cash compensation and working capital investment. In addition, in the corporate financing sector, the budgeting contained in the third revision of Rp. $44.57 \mathrm{~T}$ represents a capital injection and working capital investment for SOE and labor-intensive business restructuring. 


\section{B. Discussion}

1) Implementation of crisis management in the COVID-19 pandemic era: Currently, state-owned transportation and pharmaceutical SOEs are both experiencing threats. Each SOE in the two sectors must adjust to their respective ways in responding to the negative impacts of COVID-19 [2]. However, SOEs have not been fully responsive and effective in both sectors to policy management [2]. Pelni and pharmaceutical SOEs as a whole are still unable to adjust to the current situation, thus making these SOEs operate and employ their employees as usual, especially for pharmaceutical SOE holding, there are indications of covering up the state of raw material supply, with no accessible data. the public openly [2].

2) The efforts of several countries in managing human resources between the COVID-19 pandemic: Following are the efforts of several countries in managing human resources among the COVID-19 pandemic, including:

a) Taiwan: On 21 January 2020 Taiwan's first COVID19 case was identified, while on 28 January 2020 local transmission was detected [11]. Apart from the medical sector, the economic sector also receives subsidized assistance from the government [12]. The economic sector budget is prepared quite a large amount of NT \$ 16 billion (Rp. 8.7 trillion) to provide loans for small and medium enterprises and has been approved by the Ministry of Economic Affairs [13]. Likewise, the industrial sector and state-owned enterprises that were most affected by the pandemic had been provided with NT \$ 2 billion ( $\mathrm{Rp} 1.1$ trillion) of funds [14]. On the other hand, to provide compensation to SOE in the aviation sector and SOE in the tourism sector, the Ministry of Transportation and Communications also budgeted NT \$ 16.85 billion $(\operatorname{Rp} 9.15$ trillion) [15]. So that there is a guarantee for SOE employees to be able to work as usual.

b) Singapore: Singapore is one of the countries that have the best response in handling COVID-19. Singapore's first COVID-19 case was detected on 23 January 2020, while the first local transmission case was reported on 4 February 2020 [16]. Singapore also has a comprehensive pandemic mitigation system, namely the Disease Outbreak Response System Condition (DORSCON). These preventive measures help the government to reduce the number of COVID-19 spread in Singapore. As of April 15, 2020, there were only 3,252 positive cases with 10 people dying [17]. So that SOE in all sectors in Singapore do not experience problems and can employ their employees well.

c) South Korea: The first time a case of COVID-19 infection appeared in South Korea was on January 20, 2020, so the South Korean Government responsively and quickly raised the alert level from blue (level 1) to yellow (level 2) [18]. South Korea establishes three stages of providing support funds for affected SOEs and also to protect workers designated in a pandemic emergency. The first phase (KRW 4 trillion), to prevent an epidemic which includes a virus prevention program and a soft loan program for small businesses. In the second stage (KRW 16 trillion), it was disbursed more intensively to revitalize the economy. On March 18, 2020, providing an additional budget of KRW 11.7 trillion which can be used for: disease prevention, treatment, for affected SOEs, households, as well as small and mediumscale local businesses [19]. So that SOE in each sector can still operate and employ their employees.

d) United State: The United States (US) is one of the countries that is quite slow in dealing with COVID-19 cases. [20]. The government response was deemed slow at the start of the outbreak of COVID-19 in the US. The US government has budgeted US $\$ 8.3$ billion ( $R p 134$ trillion) through the Coronavirus Preparedness and Response Supplemental Appropriations Act to help deal with COVID-19 cases [21]. The budget for research and development of vaccines and diagnostic technology for COVID-19 is more than US \$ 3 billion (Rp. 32 trillion) allocated, around US \$ 1 billion ( $\mathrm{Rp}$. 16.1 trillion) is allocated for the procurement of medicines, health services and other medical needs. Regarding the provision of subsidies for the general public and the SOE sector affected by COVID-19, the government has approved the procurement of a stimulus package of US \$ 2 trillion (Rp. 32.2 quadrillions) through the Coronavirus Aid, Relief, and Economic Security Act (CARES Act) [22]. So that even though it is late, the SOE sector in America is still able to keep its employees working.

e) Indonesia: In Indonesia, strategic steps of ministries/institutions at the National Level in response to the COVID-19 pandemic, in the sector of the Ministry of StateOwned Enterprises (SOE) to determine strategic steps with BP Jamsostek to regulate plans related to providing incentives for workers affected by layoffs, where each worker will get an incentive of 1-5 million rupiahs for the next three months [2]. It is well known that the two SOE sectors in Indonesia are most affected by this different trend, namely the transportation sector SOE and the pharmaceutical sector SOE [2].

The minimization of transportation services to reduce virus transmission, even though it has an impact on economic losses [23]. As of 1 April 2020, it was recorded that $93 \%$ of the world's population, or around 7.2 billion people, live in countries with restrictions on the arrival of citizens of other countries [24,25]. As a result of the reduced demand for services offered, SOEs in the transportation industry, namely Garuda Indonesia, Kereta Api Indonesia (KAI), and Pelayaran Indonesia (Pelni) feel at a loss [2].

These steps are also supported by the company's decision to protect its employees. Garuda Indonesia Circular Letter Number JKTDZ / SE / 70005/2020 concerning the Work from Home (WFH) Policy which applies from 17-31 March 2020 asks employees over 50 years of age and/or have congenital diseases such as lung disease, asthma, heart disease, or diabetes 
for working from home [26]. Those who do not meet these criteria take turns [2].

As if it is inversely proportional to SOE in the transportation sector, the increase in COVID-19 cases, the demand for pharmaceutical SOE products has also increased dramatically. Since February 2020, Indonesian pharmaceutical SOEs have been operating as a pharmaceutical SOE holding. As a consequence, pharmaceutical SOEs need to ensure that basic ingredients are available on time to meet all existing demands [2]. Various SOEs, such as Pegadaian, Pelabuhan Indonesia, and Hutama Karya provide free influenza vaccine services in their work environment [2]. Government agencies also provide free flu vaccines, one of which is the Ministry of SOE [2]. The government, especially the Ministry of SOE, has also transformed hotels under its management to become emergency hospitals for handling COVID-19. The increasing demand for pharmaceutical products during the COVID-19 pandemic does not directly make pharmaceutical SOEs implement crisis management on target quickly, at least from the available data. According to the Minister of Manpower, as many as 3.05 million (as of 2 June 2020) people must be repatriated affected by COVID-19, and it is estimated that additional unemployment could reach 5.23 million. If the COVID-19 pandemic will not end soon.

\section{CONCLUSION}

Four of the five countries that have been described, namely Taiwan, Singapore, South Korea and Indonesia can be categorized as countries that are quite responsive in managing human resources during the COVID-19 pandemic. Meanwhile, one country, namely the US, can be categorized as less responsive in managing the COVID-19 pandemic. The real changes that have occurred due to COVID-19 can be seen in various aspects of life; individual behaviour, community response, business and economic behaviour, state governance, and global relations. So that some affected SOE sectors have to repatriate their employees, but there are still many SOE sectors that can keep their employees working, with time management.

\section{REFERENCES}

[1] G. Dwomoh, A. W. Luguterah, and S. B. Duah, "Hoteliers' human resource strategies for business sustainability during Covid-19 pandemic in Ghana,” J. Bus. Retail Manag. Res., vol. 14, no. 03, pp. 34-43, 2020.

[2] W. M. and Winanti and P. S., Tata Kelola Penanganan COVID-19 di Indonesia: Kajian Awal. D.I. Yogyakarta: Gadjah Mada University Press Anggota IKAPI dan APPTI, 2020.

[3] S. Solanki, "An Exploratory Study on Behavioral Science Of HR Managers to Respond to the COVID-19 Challenge," SSRN Electron. J., 2020.

[4] R. S. Putri, A. Purwanto, R. Pramono, M. Asbari, L. M. Wijayanti, and C. C. Hyun, "Impact of the COVID-19 pandemic on online home learning: An explorative study of primary schools in Indonesia," Int. J. Adv. Sci. Technol., vol. 29, no. 5, pp. 4809-4818, 2020.
[5] W. Population, "Indonesia Population 2020, World Population Review." [online]. Retreieved from https://worldpopulationreview.com/co untries/indonesia-population/

[6] R. Abdila, "Menkop Targetkan Usaha Kecil Naik Kelas dan Jumlah Wirausaha Tumbuh," Tribun Bisnis. [Online]. Retrieved from https://www.tribunnews.com/bisnis/2020/01/16/menkop-targetkanusaha-kecil-naik-kelas-dan-jumlah-wirausaha-tumbuh

[7] M. Nicola, "'The Socio-Economic Implications of the Coronavirus and COVID-19 Pandemic: A Review', International journal of surgery, 78, pp. 185-193, 2020

[8] N. F. Shalihah, "Total 1,9 Juta Pekerja Di-PHK dan Dirumahkan akibat Pandemi Virus Corona, Tren." [Online]. Retrieved from https://www.kompas.com/tren/read/2 020/04/19/081000465/total-19juta-pekerja-di-phk-dan-dirumahkan-akibat-pandemi-viruscorona?page $=$ all

[9] E. P. Fenichel, "'Economic considerations for social distancing and behavioural based policies during an epidemic," Journal of Health Economics, vol. 32, no. 2, pp. 440-451, 2013.

[10] A.W. Akhlas, "Indonesia Budget Swells, But It's Not Enough Observers Say," The Jakarta Post, 8 June 2020

[11] Y. Ming-hsuan, and Low, "Taiwan confirms first domestic case of Wuhan coronavirus." [Online]. Retrieved from https:// focustaiwan.tw/politics/202001285001

[12] Taiwan Today., "CDC implements extra inspection measures for Wuhan flights." [Online]. Retreieved from https://taiwantoday.tw/news. php?unit $=2,6,10,15,18$ \&post $=168773$

[13] N. Li, "MOEA offers assistance for virus woes." [Online]. Retrieved from https://taipeitimes.com/News/biz/ archives/2020/02/14/2003730927

[14] T. Times, "Virus Outbreak: Ministry plans coupons to stimulate economy." [Online]. Retrieved from https://taipeitimes.com/News/biz/ archives/2020/03/05/2003732072

[15] S. Shan, "Virus Outbreak: Minister vows to help major airlines survive crisis." [Online]. Retrieved from https://www. taipeitimes.com/News/taiwan/archives/2020/03/05/2003732113

[16] T. Goh, "Wuhan virus: MOH sets up a multi-ministry task force, advises against non-essential trips to Wuhan." [Online]. Retrieved from https://www.todayonline.com/singapore/covid-19- Wuhan-coronavirusoutbreak-government-put-fund-online-site- public-."

[17] MOH Singapura, "Updates on COVID-19 (Coronavirus Disease 2019) Local Situation." [Online]. Retrieved from https://www.moh. gov.sg/covid-19

[18] M. Korea, "Press Release on the first imported case of the novel coronavirus (2019-nCoV) in Korea." [Online]. Retrieved from https://www.mohw.go.kr/eng/nw/nw0101vw.jsp?PAR_MENU_ $\mathrm{ID}=1007 \& \mathrm{MENU}$ ID $=100701 \&$ page $=2 \&$ CONT_SEQ $=352468$

[19] M. Korea, "Corona 19 Confirmed by the National Assembly for additional revision budget in 2020 to minimize ripple effects and overcome." [Online]. $\quad$ Retreieved from http://www.moef.go.kr/nw/nes/detailNesDtaView. do?menuNo=4010100\&searchNttId=MOSF_000000000032703 \&searchB

[20] F. Ghitis, “Trump's wishful thinking won't stop coronavirus impact." [Online]. Retrieved from https://edition.cnn.com/2020/02/25/ opinions/trump-downplay-coronavirus-ghitis/index.html

[21] K. Breuninger, "Senate passes $\$ 8.3$ billion emergency coronavirus package, sending bill to Trump's desk." [Online]. Retrieved from https://www.cnbc.com/2020/03/05/senate-passes-8point3- billioncoronavirus-bill-sending-it-to-trumps-desk.html

[22] M. Murray Jr, F., Rifis, J., Imbrogno, L., Class, J., Sierawski, M., D Vito, J., Foley, K., dan Donadio, "The Coronavirus Aid, Relief, and Economic Security Act ('CARES Act') Is Enacted into Law." [Onine]. Retrieved from https://www.foley.com/en/ insights/publications/2020/03/coronavirus-cares-act-enacted-into-law 
[23] J. Adda, "'Economic Activity and the Spread of Viral Diseases: Evidence from High-Frequency Data," The Quarterly Journal of Economics, vol. 131, no. 2, pp. 891-941, 2016.

[24] P. Connor, "More than nine-in-ten people worldwide live in countries with travel restrictions amid COVID-19, Pew Research Center," 2020.

[25] S. Laoli and N. Mayasari, "Pendapatan Garuda Indonesia (GIAA) Babak Belur Akibat Virus Corona," [Online]. Retrieved from https://industri.kontan.co.id/news/pendapatan-garuda-indonesia- giaababak-beluar-akibat-virus-corona?page=all

[26] A. Rahma, "Garuda Indonesia Terapkan Kebijakan Kerja dari Rumah Mulai Hari Ini," [Online]. Retrieved from https://www.liputan6. com/bisnis/read/4204124/garuda-indonesia-terapkan-kebijakan- kerjadari-rumah-mulai-hari-ini 